\title{
Wiggins, G., \& McTighe, J. (2005) Understanding by design (2nd ed.). Alexandria, VA: Association for Supervision and Curriculum Development ASCD
}

Alejandro Dávila'

\author{
Citation/ Para citar este Artículo: Dávila, A. (2017). Wiggins, G., \& McTighe, J. (2005) Understanding by design (2nd ed.). Alexandria, VA: Association for \\ Supervision and Curriculum Development ASCD. Colomb. Appl. Linguist. J., 19(1), pp. 140-142. \\ Received: 14-Dec-2015 / Accepted: 26-Dec-2016 \\ DOI: http://dx.doi.org/10.14483/calj.v19n1.11490
}

Writers and curriculum experts Grant Wiggins and Jay McTighe present in this second edition of their best-seller Understanding by Design not only a framework to work on curriculum design in a more comprehensive, overarching, and thorough way but also a pedagogical as well as educational perspective that encourages teachers, students, administrative staff, and even policy makers, to reconsider the purpose, objectives, and impact that a thoughtful curriculum design can have for the community in which it is implemented. In this book, the authors provide a clear depiction of both the theoretical foundations and the practical elements putting everything together for the construction of the design of learning. The different chapters follow their three-staged backward design idea which I consider useful for a full understanding of this innovative way of planning and designing a curriculum.

The first seven chapters deal with the most important aspects of the curriculum design, namely, established goals, understandings, essential questions, skills, and knowledge. In chapter one, the main components and pedagogical stance of the tool called backward design are presented. The backward design tool is shown as a template for better planning and understanding of both the teaching and learning processes. Here the authors call our attention on two of the most recurrent mistakes of traditional design, coverage and activityoriented design. At this respect, it is important to remark that many times teachers, who are the ones in charge of developing the curriculum, focus their planning in assuring that they cover all of the topics suggested either by governmental policies such as standards, or concentrate more on the type of activity to be carried out by students paying little attention to the real purpose, usefulness, and impact on students understanding of the topic.

The second chapter is remarkable as it touches the topic of understanding, reflecting upon the way teachers understand understanding taking into account that it is one, if not the ultimate, goal in education-to look for the best way for our students to understand something. Following (Dewey, 1933) and (Perkins, 1992), Wiggins and McTighe reflect upon this concept and characterise it as a mental construct made by the human mind to take sense of many pieces of knowledge. It also involves transferring what the student has learnt to new situations and using this knowledge creatively, flexibly, and fluently in problems.

The third chapter is devoted to guide those committed in curriculum design to state clear and reachable objectives. Here, they remark the limitations that the use of standards has. First, teachers may face an overload for the short period of time allowed in schools. Second, they are either too big or unreachable or too small missing the big ideas of the concept. Finally, standards are open to an infinite number of interpretations which defeat the initial aim of the implementation of standards $\overline{1}$ Doctorado Interinstitucional en Educación - Universidad Distrital Francisco José de Caldas, Bogotá, Colombia. intermediatealejo@
yahoo.com 
that is to provide "clear, consistent and coherent educational goals" (p. 62).

Complementing the ideas stated in chapter two, in the chapter five, the authors propose an alternative perspective in the conception of the concept understanding. By developing a multifaceted view of this concept, they consider that when a person understands there are six different aspects which, instead of taking place one after another as in Bloom's taxonomy (cited in Anderson, Krathwohl, E Bloom, 2001), may occur simultaneously. Those facets are: explanation, interpretation, application, perspective, empathy, and self-knowledge.

In order to conclude the first stage of backward design (identify desired results), chapters five and six provide useful insights into how to formulate essential questions which are defined as the best way to engage students and teachers in the process of understanding. It is through working and putting into practice the concepts previously described that in chapter six, the readers are asked to work on a kind of DIY workshop whose purpose is to guide the curriculum designer into a practical exercise of application and reflection upon the way of crafting essential questions and understandings.

The second stage of backward design (determine acceptable evidence) is introduced by the authors through a shift in the vision teachers have about assessment. Wiggins and McTighe suggest that before going on to the creation of any activity, teachers and curriculum designers must ask themselves questions like: "what would count as evidence of successful learning? Or what counts as evidence of the understanding sought?" (p. 146). Although out of the routine of carrying out assessment, the role of teachers should be characterized as an assessor rather than an evaluator, that is thinking first about the activities that will be the evidence of the evaluation, reflecting upon what is going to be expected from students' performance, and leaving the activity creation for the last step may pose a challenge for teachers who are used to getting their hands on the formulation of exercises for students. One positive result coming from this change is that the evidence would be more grounded in the real contexts of those immersed in the process of teaching and learning.

In chapter eight, the topics of criteria and validity are discussed. Following the idea that understanding and the performance that students display of it cannot be assessed by a single and correct answer, the authors claim that a need for the construction of a judgement based on criteria should be taken. They use rubrics as criterion-based tools to assess students' understanding and performance of the different concepts, topics, and ideas posed in the curriculum. One of the important aspects in the implementation of rubrics is that through them teachers should be able to differentiate students' results if they have developed sophisticated understanding or if they are just retelling what they were taught.

The third and last stage of the backward design (plan learning experiences and instruction) is described in chapter nine as the process in which teachers, more than thinking as designers and establishing what activities students will do, are encouraged to think and see student as the person he/she is beyond the classroom. Teachers in this stage should reflect about the needs students have in terms of knowledge, cognitive schemata, and resources to achieve the desired understandings and performances established in the first two stages. They also provide the idea of the WHERETO ${ }^{2}$ elements for a pertinent and engaging activity plan.

Having explored with the reader all of the stages implied in backward design, the authors return to the idea of understanding in chapter ten. This chapter is linked to the reflections made in chapters one and two, but at this time they offer a deeper account on what they imply in the curricular design process. Concepts such as coverage and uncoverage together with useful ideas of how and when to teach guide the teacher toward more purposeful thinking. Moreover, they claim the need to implement more strategies of formative assessment in the design of teaching and learning experiences.

\footnotetext{
2 The authors use this acronym which stands for where, hook, equip, rethink, evaluate, tailored, and organized to guide the planning of activities for students.
} 
In the last three chapters, Wiggins and McTighe provide the big picture of backward design and how it could fit into the general curriculum schema that an institution can have. The reflections made here guide the teacher as curriculum designer and developer to adopt a critical position towards his or her work until that moment. Furthermore, they recognize that the proposed curriculum design is not linear and teachers may be constantly going back and forth while constructing it.

The ideas expressed in this book, the way it is written by providing real examples taken from real classrooms, and the permanent invitation to reflect upon the teaching practice of who is reading it captivates the reader while motivating him or her to take a chance to shift those practices in both the curriculum design and day-to-day classes. In addition, this book offers more than the presentation of a comprehensive framework for better curriculum planning, assessment, and implementation. It inspires a new and powerful way of seeing education in any area or level. It invites teachers and other agents in the process of education to shift their perspectives towards students, assessment, and teaching for one in which the focus is not on knowledge but rather on the developing of real understanding. We may have seen this idea in other pedagogical approaches or methods, but what makes this proposal interesting is that it guides teachers step by step in the creation and implementation of the proposal while providing enough practical support.

To sum up, more than a book, Understanding by Design could be a great contribution to the field of ELT in that it allows language teachers to truly develop interdisciplinary work, take the foreign language as a real vehicle of communication and not an object of study, encourage students to see language as a tool to understand their reality and inspire other members of the process of education to take active roles.

\section{References}

Anderson, L. W., Krathwohl, D. R., E Bloom, B. S. (2001). A taxonomy for learning, teaching, and assessing: A revision of Bloom's taxonomy of educational objectives. New York, NY: Longman.

Dewey, J. (1933). How we think: A restatement of the relation of reflective thinking to the educative process. Boston, MA: Heath and Company.

Perkins, D. (1992). Smart schools: From training memories to educating minds. New York, NY: Free Press.

Wiggins, G., \& McTighe, J. (2005). Understanding by design (2nd ed.). Alexandria, VA: Association for Supervision and Curriculum Development ASCD. 